\title{
Gall midges (Diptera: Cecidomyiidae: Cecidomyiinae) of Belarus
}

\section{Гамлицы (Diptera: Cecidomyiidae: Cecidomyiinae) Беларуси}

\author{
Marcela Skuhravá ${ }^{1}, V^{\prime} c l a v ~ S k u h r a v y^{1}$, Sébastien Carbonnelle ${ }^{2}$ \\ Марџела Скуграва ${ }^{1}$, Ваџлав Скугравийㅁ, Себастьян Карбонелее ${ }^{2}$
}

\footnotetext{
${ }^{1}$ Bítovská 1227/9, 14000 Praha, Czech Republic. E-mail: marcela.skuhrava@gmail.com

2 Place Saint Lambert 2, 5660 Aublain, Belgium. E-mail: carbogalles@gmail.com
}

KEY WORDS: Distribution, zoogeography, economic importance, plant-insect interactions, Cecidomyiidae, Diptera, Belarus, Palaearctic region.

КЛЮЧЕВЫЕ СЛОВА: Распространение, зоогеография, экономическое значение, взаимодействия растений с насекомыми, Cecidomyiidae, Diptera, Беларусь, Палеарктический регион.

ABSTRACT. The known gall midge fauna of Belarus includes 73 species. Most of these species were found by earlier researchers in the period 1881-2012. During investigations in the Berezinsky Biosphere Nature Reserve in 201611 species of gall midges were found; 5 of them are first records from Belarus: Giraudiella inclusa (Frauenfeld, 1862), Rabdophaga repenticola (Stelter, 1964), Semudobia betulae (Winnertz, 1853), Semudobia skuhravae Roskam, 1977 and Semudobia tarda Roskam, 1977. Belarus has the lowest species density: only 19 species have been recorded in an area of $1000 \mathrm{~km}^{2}$. Zoogeography: 42 gall midge species $(57 \%)$ are Euro-Siberian and 30 gall midge species (41\%) are European species. Plant-insect interactions: gall midges are associated with 58 host plant species belonging to 25 plant families. 32 species of host plants are trees and shrubs and 26 species are herbaceous plants. Populus tremula, hosting 7 gall midge species, is the host plant with the highest number of associated species. Economic importance: 7 gall midge species associated with agricultural plants are potential pests: Mayetiola destructor (Say, 1817), larvae of which damage stems of cereals; Contarinia pyrivora (Riley, 1886), larvae of which develop inside fruits of Pyrus communis; Dasineura pyri (Bouché, 1847), attacking young developing leaves of Pyrus communis, mainly in nurseries; Dasineura mali, which is a serious pest of young apple trees and scions in orchards and in nurseries; Dasineura tetensi (Rübsaamen, 1891), attacking young leaves of Ribes nigrum; Dasineura tortrix (F.Löw, 1877), damaging young leaves of various species of cultivated Prunus; Lasioptera rubi (Schrank, 1803), damaging stems of cultivated species of the genus $R u$ bus. Annotated lists of gall midge species and of host plants associated with gall midges are given.

РЕЗЮМЕ. Из Беларуси известно 73 вида галлиц. Большинство из них было обнаружено исследователями в период 1881-2012 гг. В ходе исследований в Березинском биосферном заповеднике в 2016 году было найдено 11 видов галлиц, 5 из которых впер- вые указывается для Беларуси: Giraudiella inclusa (Frauenfeld, 1862), Rabdophaga repenticola (Stelter, 1964), Semudobia betulae (Winnertz, 1853), Semudobia skuhravae Roskam, 1977 и Semudobia tarda Roskam, 1977. Беларусь имеет самое низкое разнообразие: только 19 видов были зарегистрированы на площа-

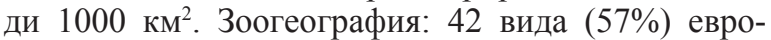
сибирские и 30 видов (41\%) - европейские. Галлицы связаны с 58 видами растений-хозяев, принадлежащими к 25 семействам. 32 вида растений-хозяев - деревья и кустарники, а 26 видов - травянистые растения. Наибольшее число видов (7) связано с Populus tremula. Экономическое значение: 7 видов галлиц, связанных с сельскохозяйственными растениями, являются потенциальными вредителями: Mayetiola destructor (Say, 1817), личинки которых повреждают зерновые культуры; Contarinia pyrivora (Riley, 1886), личинки которых развиваются в плодах Pyrus communis; Dasineura pyri (Bouché, 1847 ) повреждает молодые развивающиеся листья Pyrus communis, главным образом в питомниках; Dasineura mali - серьезный вредитель молодых яблонь в садах и питомниках; Dasineura tetensi (Rübsaamen, 1891) повреждает молодые листья Ribes nigrum; Dasineura tortrix (F.Löw, 1877) — молодые листья различных видов культивируемых Prunus; а Lasioptera rubi (Schrank, 1803) - стебли культивируемых видов рода Rubus. Даны аннотированные списки видов галлиц и их растений-хозяев.

\section{Introduction}

Gall midges forming the family Cecidomyiidae belong to one of the most species-rich families of Diptera. Gagné and Jaschhof [2017] list 6590 species in 850 genera of living and fossil gall midges in the world. In total, 3113 species in 344 genera are described for the Palaearctic Region with about 1800 species in 270 genera for Europe [Skuhravá, 2006]. Based on modern taxonomical studies, five subfamilies, i.e. Cecidomyii- 
nae, Lestremiinae s.str, Micromyinae, Porricondylinae s.str. and Winnertziinae form the family Cecidomyiidae [Jaschhof, Jaschhof, 2009].

Adults of gall midges are usually only $0.5-3 \mathrm{~mm}$ long and rarely reach sizes up to $8 \mathrm{~mm}$. They have long antennae, relatively large wings with reduced venation and long legs. Larvae are phytophagous, mycetophagous or saprophagous. Some larvae are zoophagous. Larvae of phytophagous species cause galls (Latin: cecidium) on various organs of host plants (hence the common name "gall midges") or live free within flower heads or stems of plants and do not induce galls [Mamaev, 1962, Skuhravá et al., 1984a, b; Skuhravá, 1997].

Gall midges and their galls are common components of all biotopes in natural ecosystems. Some species of gall midges occurring on cultivated plants, forest trees and shrubs may cause damage to their host plant and are considered to be pests [Darvas et al., 2000, Skuhravá, Roques 2000]. Some zoophagous species may be classed as beneficial and are used for biological control of aphids and other plant pests [Harris, 1973].

Data on the occurrence of species of the family Cecidomyiidae in the Palaearctic Region were summarised for the first time by Skuhravá [1986]. At that time only one species of gall midge was known to occur in Belarus: Hybolasioptera fasciata (Kieffer, 1904), larvae of which cause galls on various cereals. Galls of this species were found at Mogilev in eastern Belarus by Russian entomologist K.E. Lindeman (1844-1929) in the year 1880 and described as Cecidomyia cerealis by Lindeman [1881]. While researching data on the occurrence of gall midges in adjacent countries, we found several articles in which are recorded galls of gall midges that refer to the present territory of Belarus (in the past these localities belonged to Lithuania, found near Vilnius). Fiedorowiczówna [1931] found 123 plant galls of which 26 were caused by Cecidomyiidae, Perepeczko-Baumanowa [1935] found galls of 22 species of Cecidomyiidae of which 9 were not recorded by the previous author. Ostrowski [1926] found 120 plant galls of which 25 species was caused by Cecidomyiidae. Petrov [2004] gave 8 species of gall midges as common in Belarus and later listed 34 species for the country [Petrov, 2010].

In April 2016 one of us, S. Carbonnelle, was invited by Dr. Alexander Lukashuk to take part in investigations in the Berezinsky Biosphere Nature Reserve. He found there galls of nineteen gall-causing invertebrates. Of them four species belong to Eriophyidae (Acari), two species to Cynipidae (Hymenoptera), one species to Adelgidae (Hemiptera), one species to Chloropidae (Diptera) and eleven species to Cecidomyiidae (Diptera).

In this article we summarize present knowledge on gall midges in Belarus together with new records of gall midge species found during the expedition in the Berezinsky Biosphere Nature Reserve in the year 2016 and evaluate results from the zoogeographical point of view (Fig. 1).

\section{Study area}

Belarus, officially the Republic of Belarus, is a landlocked country in Eastern Europe bordered by Russia to the northeast, Ukraine to the south, Poland to the west, and Lithuania and Latvia to the northwest. It occupies an area of $207,600 \mathrm{~km}^{2}$ and over $40 \%$ of its area is forested. It has many streams and 11,000 lakes. Three major rivers run through the country: the Neman, the Pripyat, and the Dnieper. The Neman flows westward towards the Baltic Sea and the Pripyat flows eastward to the Dnieper; the Dnieper flows southward towards the Black Sea. The highest point is Dzyarzhynsk Hill at $345 \mathrm{~m}$ a.s.1., the lowest point is on the Neman River at $90 \mathrm{~m}$ and the average elevation of Belarus is $160 \mathrm{~m}$ a.s.l. The country is in the transitional zone between continental climates and maritime climates.

The country is divided into six regions (in parentheses their administrative centre): Brest Region (Brest), Gomiel Region (Gomel), Grodno Region (Grodno), Mogilev Region (Mogilev), Minsk Region, Vitebsk Region and the City of Minsk, which has the status of an independent administrative-territorial unit.

Belarus has four National Parks and many interesting parts of nature are protected in natural reserves. The Berezinsky Biosphere Nature Reserve occupies an area of $852 \mathrm{~km}^{2}$ and was established in 1925 for the protection of rare animal species. It is situated in the northern part of Belarus $120 \mathrm{~km}$ from Minsk. In 1979, Berezinsky Reserve received the status of a biosphere reserve for its biological diversity and unique combinations of natural conditions. It includes four types of ecosystems: forests, bogs, water reservoirs and meadows.

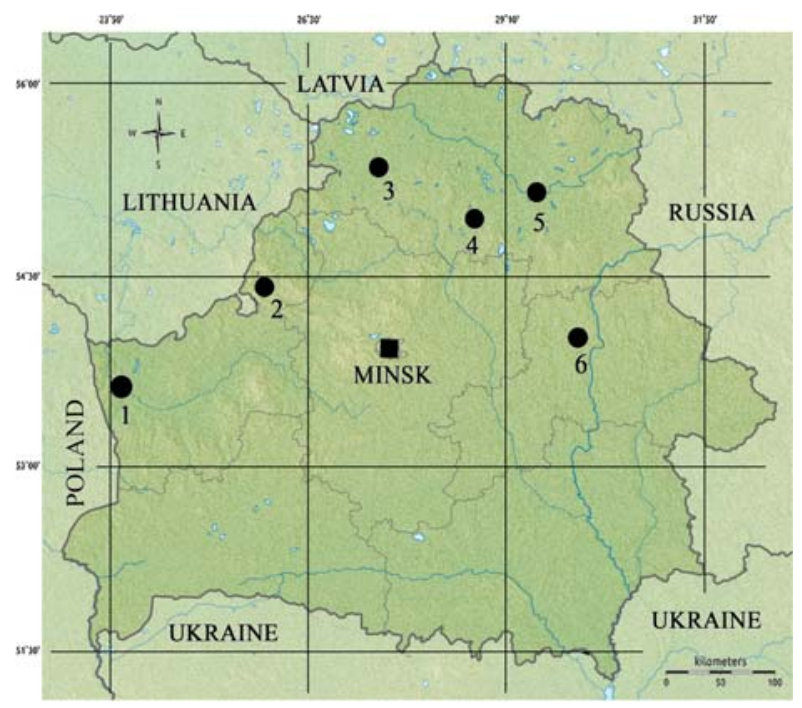

Fig. 1. Map of Belarus with the capital city, Minsk, and with the main areas where investigations of gall midges have been undertaken: 1 - Grodno, 2 - Oszmiana, 3 - Szarkowszczyzna, 4 Berezinsky Biosphere Nature Reserve, 5 - Dzisna, 6 - Mogilev.

Рис. 1. Карта Беларуси с столицей (Минск) и основныеми районами изучения галлиц: 1 - Гродно, 2 - Ошмяны, 3 Шарковщина, 4 - Березинский биосферный природный заповедник, 5 - Дрозды, 6 - Могилев. 


\section{Material and methods}

We gathered data on the occurrence of gall midges in Belarus from articles of various researchers published in scientific journals. The main method in studies of distribution of gall midges is collecting galls. In the year 2016 one of the authors (S.C.) collected galls of gall midges and other gall-causers in the Berezinsky Biosphere Nature Reserve. Identication of galls is based on the keys of Buhr [1964-1965] and Houard [1908-1909], identication of larvae on Möhn [1955] and Mamaev and Krivosheina [1993], and of adults on Skuhravá [1997]. Nomenclature of gall midge species is based on Skuhravá [1986, 1989] and Gagné and Jaschhof [2014], nomenclature of host plants on Tutin et al. [1964-1980].

\section{Localities and areas examined}

Dzisna, a city in the Vitsebsk Voblast, on the left bank of the Daugava River, near the confluence of Dysna.

Grodno, now Hrodna, $137 \mathrm{~m}$ a.s.l., a city in western Belarus, situated on the Neman River close to the borders of Poland and Lithuania in western Belarus.

Mogilev, 192 m a.s.1., a city in eastern Belarus, the administrative centre of Mogilev Region.

Oszmiana, now Ashmyany, District Hrodna), a town in Grodno Region, situated in the basin of the Oshmianka River.

Szarkowszczyzna, $127 \mathrm{~m}$ a.s.1., small town in the Vitebski Region.

Berezinsky Biosphere Nature Reserve, situated in the northern part of Belarus about $120 \mathrm{~km}$ from Minsk, along the River Berezina; it includes many small tributaries and many lakes and is covered with rich vegetation.

\section{Results}

We sumarized knowledge on gall midges in Belarus. At present the known fauna of gall midges includes 73 species. Most of these species were found by earlier researchers in the period 1881-2012. During investigations of gall-causing arthropods in the Berezinsky Biosphere Nature Reserve in 201611 species of gall midges were found; 5 of them are first records from Belarus: Giraudiella inclusa (Frauenfeld, 1862), Rabdophaga repenticola (Stelter, 1964), Semudobia betulae (Winnertz, 1853), Semudobia skuhravae Roskam, 1977 and Semudobia tarda Roskam, 1977.

In the following part we give all species of gall midges known to occur in Belarus in the annotated list which is followed by the list of host plants attacked by gall midges. At the end we evaluate results from various points of view.

\section{Annotated list of species}

The following data are given for each species in the annotated list: species name, author and date of description, synonyms (if any), short description of the biology (if known), shape of the gall, host plant species and plant family, occurrence (name of the locality where the gall was found together with reference to citation), and at the end the type of distribution in the Palaearctic region.

Anisostephus betulinus (Kieffer, 1889)

BIOLOGY. Larvae cause parenchymous galls on leaves of Betula pubescens Ehrh. and B. pendula Roth. (Betulaceae). Only one generation develops a year. Overwintering in the soil. OCCURENCE: Grodno [Ostrowski, 1926], Oszmiana [Perepeczko-Baumanowa, 1935], rare [Petrov, 2010].

DISTRIBUTION: Eurosiberian.

Aphidoletes aphidimyza (Rondani, 1847)

BIOLOGY. Larvae feed predaciously on many species of aphids (Hemiptera: Aphididae) on various host plants. There are several generations per year. Larvae pupate in cocoons. This species is used for biological control of aphids [Harris, 1966, 1973]. 1994].

OCCURENCE: without locality [Koltun, Meleshko,

\section{DISTRIBUTION: Holarctic.}

Contarinia carpini Kieffer, 1897

BIOLOGY. White larvae produce leaf galls on Carpinus betulus L. (Corylaceae). One generation develop per year. Hibernation in the soil.

OCCURENCE: rare [Petrov, 2010].

DISTRIBUTION: European.

Contarinia coryli (Kaltenbach, 1859)

Diplosis corylina F.Löw, 1878

BIOLOGY. Yellow larvae develop in swollen catkins of Corylus avellana L. (Corylaceae).

OCCURENCE: Grodno [Ostrowski. 1926], Oszmiana [Perepeczko-Baumanowa, 1935].

DISTRIBUTION: Eurosiberian, a large area extending to China.

Contarinia petioli (Kieffer, 1898)

Harmandia petioli Kieffer, 1898.

Syndiplosis winnertzi Rübsaamen, 1910.

BIOLOGY. Orange coloured larvae cause globular galls on leaf petioles on Populus tremula L. (Salicaceae). One generation develops per year. Larvae hibernate in the soil.

OCCURENCE: Grodno [Ostrowski, 1926], Szarkowszczyzna [Fiedorowiczowna, 1931], rare [Petrov, 2004, 2010].

DISTRIBUTION: Eurosiberian.

\section{Contarinia pyrivora (Riley, 1886)}

BIOLOGY. Many yellowish-white larvae live inside the misshapen and enlarged fruitlets of Pyrus communis L. (Rosaceae). The infested fruitlets dry up and crack, later falling to the ground. Attacked fruits are unshapely and enlarged. Before then the fully-grown larvae leave attacked fruits and fall to the soil where they hibernate. One generation develops per year. It is a major pest of pear [Darvas et al., 2000].

OCCURENCE: Grodno [Ostrowski, 1926].

DISTRIBUTION: Eurosiberian (Holarctic).

\section{Contarinia tiliarum (Kieffer, 1890)}

BIOLOGY. Yellow larvae cause conspicuous globular swellings on flower stalks, leaf petioles and young twigs of Tilia cordata Mill. and T. platyphyllos Scop. (Tiliaceae). One generation develops per year. Larvae hibernate in the soil.

OCCURENCE: Oszmiana [Perepeczko-Baumanowa, 1935], rare [Petrov, 2010].

DISTRIBUTION: Eurosiberian. 
Cystiphora sonchi (Vallot, 1827)

Cecidomyia sonchi Bremi, 1847.

Cecidomyia sonchi F.Löw, 1875.

BIOLOGY. Yellow-whitish larvae cause pustule galls on the leaves of Sonchus oleraceus L. and S. arvensis L. (Asteraceae). Two or more generations develop per year. Some larvae pupate in galls, some in the soil. Larvae hibernate in the soil. $1935]$

OCCURENCE: Oszmiana [Perepeczko-Baumanowa,

DISTRIBUTION: Eurosiberian, introduced into Canada for biological control.

Dasineura affinis (Kieffer, 1886)

BIOLOGY. At rst white, later pale orange coloured larvae produce galls on the young leaves of Viola reichenbachiana Jord. ex Boreau (=V. sylvestris Lam., V. sylvatica Fries) (Violaceae). Leaf margins are rolled up and thickened. Several larvae develop in one roll where they pupate in white cocoons. Two or more generations develop per year.

OCCURENCE: Grodno [Ostrowski, 1926], Oszmiana [Perepeczko-Baumanowa, 1935].

DISTRIBUTION: European, occurring as far as Africa.

Dasineura daphnes (Kieffer, 1901)

BIOLOGY. Whitish larvae live gregariously in large galls at vegetative tips of Daphne mezereum L. and other species (Thymelaeaceae). Only one generation develops per year. Larvae hibernate in the soil.

OCCURENCE: Nacionalnyj park Belovezskaja Puszta [Petrov, 2010].

DISTRIBUTION: European.

Dasineura dioicae (Rьbsaamen, 1895)

BIOLOGY. Yellowish white larvae cause galls on Urtica dioica L. (Urticaceae). Leaf margins are slightly thickened and curled upwards.

OCCURENCE: Oszmiana [Perepeczko-Baumanowa, 1935].

DISTRIBUTION: European.

Dasineura fraxini (Bremi, 1847)

BIOLOGY. Orange larvae cause swellings of the midvein on the leaflets of Fraxinus excelsior L. (Oleaceae). Usually one generation, rarely two generations develop per year. Larvae hibernate and pupate in the soil. It is classed as a minor pest [Skuhravá, Roques, 2000]. OCCURENCE: Szarkowszczyzna [Fiedorowiczowna, 1931], Oszmiana [Perepeczko-Baumanowa, 1935], rare [Petrov, 2010].

DISTRIBUTION: European, occurring as far as Africa.

Dasineura galiicola (F.Löw, 1880)

BIOLOGY. Orange-yellow larvae form artichoke-shaped galls on Galium uliginosum L. (Rubiaceae). OCCURENCE: Grodno [Ostrowski, 1926].

DISTRIBUTION: Eurosiberian.

Dasineura hyperici (Bremi, 1847)

BIOLOGY. Orange-yellow larvae cause leaf bud galls on Hypericum perforatum L. and other species (Hypericaceae). OCCURENCE: Oszmiana [Perepeczko-Baumanowa, 1935]. DISTRIBUTION: European.

Dasineura kiefferiana (Rübsaamen, 1891)

BIOLOGY. Pale yellow larvae live in rolled leaf margins of Epilobium angustifolium L. (Onagraceae).

OCCURENCE: Grodno [Ostrowski, 1926].

DISTRIBUTION: Eurosiberian.
Dasineura mali (Kieffer, 1904)

BIOLOGY. At first white, later red larvae develop in rolled leaf margins of Malus domestica Borkh. (Rosaceae). Infested leaves drop prematurely. Two or more generations develop per year. One part of larvae pupates in galls, other part drops to the ground and pupate in the soil. It is a serious pest of young apple trees and scions in orchards and in nurseries [Darvas et al., 2000].

OCCURENCE: rare [Petrov, 2010].

DISTRIBUTION: Eurosiberian, Holarctic, immigrant in North America, Argentina and New Zealand.

\section{Dasineura populeti (Rübsaamen, 1889)}

BIOLOGY. White larvae develop in rolled leaf margins on shoots of Populus tremula L. (Salicaceae). Several generations develop per year. Larvae pupate in the soil.

OCCURENCE: frequent, outbreaks from time to time [Petrov, 2010].

DISTRIBUTION: Eurosiberian.

Dasineura pteridicola (Kieffer, 1901)

BIOLOGY. White larvae develop in inconspicuous galls on leaflet margins of Pteridium aquilinum (L.) Kuhn (Dennstaedtiaceae). The margin is only bent, not rolled. Full-grown larvae leave the gall, drop to the soil where they hibernate. One generation develops a year. 1931].

OCCURENCE: Szarkowszczyzna [Fiedorowiczowna,

DISTRIBUTION: European.

Dasineura pyri (Bouché, 1847)

BIOLOGY. White larvae develop in curled and rolled leaf margins of Pyrus communis L. (Rosaceae). Two or more generations develop per year. Larvae pupate in the galls or in the soil. It may be occasionally a serious pest of pears, especially on young trees [Darvas et al., 2000]. OCCURENCE: Grodno [Ostrowski, 1926], rare [Petrov, 2010].

DISTRIBUTION: Eurosiberian, immigrant in eastern Nearctic and New Zealand.

\section{Dasineura rosae (Bremi, 1847)}

Cecidomyia rosarum Hardy, 1850.

Wachtliella rosarum (Hardy, 1850): auctorum.

BIOLOGY. Orange coloured larvae cause galls on leaflets of Rosa canina L. and some other species of Rosa (Rosaceae). The attacked leaflet is folded along the midvein and swollen, forming a chamber where larvae develop. Several generations develop per year. Full-grown larvae leave galls; fall to the soil where they pupate.

OCCURENCE: rare, sometimes frequent [Petrov, 2010].

DISTRIBUTION: Eurosiberian, including Kazakhstan.

Dasineura serotina (Winnertz, 1853)

BIOLOGY. White larvae cause leaf bud galls on Hypericum humifusum L. (Hypericaceae). 1931].

OCCURENCE: Szarkowszczyzna [Fiedorowiczowna,

DISTRIBUTION: European.

Dasineura sibirica (Marikovskij, 1962)

BIOLOGY. Larvae cause galls from folded leaflets of Caragana arborescens Lam. (Fabaceae).

OCCURENCE: rare, but it may occur as a pest on shrubs in hedges [Petrov, 2010].

DISTRIBUTION: Eurosiberian. 
Dasineura sisymbrii (Schrank, 1803)

BIOLOGY. Orange coloured larvae cause spongy galls on stems and inflorescences of Rorippa palustris (L.) Bess. (original description), other species of the genus Rorippa and also of Barbarea and Sisymbrium (Brassicaceae). Two or three generations develop in one year. Larvae pupate in the galls.

OCCURENCE: Szarkowszczyzna [Fiedorowiczowna, 1931], Oszmiana [Perepeczko-Baumanowa, 1935].

DISTRIBUTION: Eurosiberian.

\section{Dasineura sodalis (F.Löw, 1877)}

BIOLOGY. White larvae live as inquilines in the galls of Dasineura tortrix (F.Löw) on Prunus spinosa L. (Rosaceae). 1931].

OCCURENCE: Szarkowszczyzna [Fiedorowiczowna,

DISTRIBUTION: European.

Dasineura tetensi (Rübsaamen, 1891)

Perrisia ribicola Kieffer, 1909.

BIOLOGY. At rst white, later yellowish larvae live in folded and twisted leaves on terminal shoots of Ribes nigrum L. (Grossulariaceae). Three or four generations develop per year. Larvae pupate in the soil. Occasionally $D$. tetensi may be a serious pest of black currant [Darvas et al., 2000]. 1931]

OCCURENCE: Szarkowszczyzna [Fiedorowiczowna,

\section{DISTRIBUTION: Eurosiberian.}

\section{Dasineura tiliae (Schrank, 1803)}

Cecidomyia tiliamvolvens Rübsaamen, 1889.

BIOLOGY. Red-yellow or orange coloured larvae cause galls on leaves of Tilia platyphyllos Scop.and T. cordata Mill. (Tiliaceae). The gall is formed of rolled leaf margin that is fleshy and swollen. One generation develops per year. Larvae hibernate in the soil.

OCCURENCE: Grodno [Ostrowski, 1926], Szarkowszczyzna [Fiedorowiczowna, 1931], rare [Petrov, 2010].

DISTRIBUTION: Eurosiberian.

Dasineura tortilis (Bremi, 1847)

Cecidomyia alni F.Löw, 1877.

BIOLOGY. At first yellow, then orange red larvae cause galls on Alnus glutinosa (L.) Gaertn. and A. incana (L.) Moench. (Betulaceae). Attacked leaf is folded upwards and the midvein and bases of lateral veins are thickened. One generation develops per year. Larvae hibernate in the soil.

OCCURENCE: without locality [Petrov, 2004], frequent up to very frequent [Petrov, 2010].

DISTRIBUTION: European.

\section{Dasineura tortrix (F.Löw, 1877)}

BIOLOGY. White larvae live gregariously in terminal leaf bud galls on Prunus spinosa L. and other species of the genus Prunus (Rosaceae). The gall is fusiform, terminal leaves are massed together and the leaf margins are loosely rolled. One generation develops per year. Larvae hibernate in the soil. It is classed as a minor pest of young plum trees, mainly in fruit-grower nurseries [Darvas et al., 2000].

OCCURENCE: Szarkowszczyzna [Fiedorowiczowna, 1931].

\section{DISTRIBUTION: European.}

Dasineura ulmaria (Bremi, 1847)

BIOLOGY. Yellowish white larvae cause leaf galls on Filipendula ulmaria (L.) Maxim. (Rosaceae). The gall is hemispherical on the upper side and cylindrical on the lower leaf side. Each gall contains one chamber where a larva develops and pupates. Two or three generations develop per year.

OCCURENCE: Szarkowszczyzna [Fiedorowiczowna, 1931], Oszmiana [Perepeczko-Baumanowa, 1935].

DISTRIBUTION: Eurosiberian.

Dasineura urticae (Perris, 1840)

BIOLOGY. Whitish-orange larvae cause irregular galls on leaves, stems and flower stalks of Urtica dioica L. (Urticaceae). The gall is rounded, unilocular with a mouth-like opening on the upper surface of the leaf. Two or more generations develop per year. Larvae pupate in the soil.

OCCURENCE: Grodno [Ostrowski, 1926], Szarkowszczyzna [Fiedorowiczowna, 1931], Oszmiana [Perepeczko-Baumanowa, 1935].

DISTRIBUTION: Eurosiberian.

\section{Dasineura violae (F.Löw, 1880)}

BIOLOGY. Pale orange-red larvae live gregariously in rosette leaf galls on Viola tricolor L. ssp. arvensis Murr. (Violaceae). Larvae pupate in the galls in white cocoons. Several generations develop per year.

OCCURENCE: Grodno [Ostrowski, 1926].

DISTRIBUTION: European.

\section{Dasineura vitisidaea (Kieffer, 1909)}

BIOLOGY. Whitish larvae cause galls on vegetative tips of Vaccinium vitis-idaea L. (Ericaceae). Kieffer (1909) described the gall only.

OCCURENCE: rare [Petrov, 2010].

DISTRIBUTION: European.

Didymomyia tiliacea (Bremi, 1847)

Cecidomyia tiliacea Bremi, 1847.

Cecidomyia frauenfeldi Kaltenbach, 1872.

Hormomyia reaumuriana F.Löw, 1878.

BIOLOGY. Larvae produce hard woody galls on leaves of Tilia platyphyllos Scop. and T. cordata Mill. (Tiliaceae). The gall is conical on the upper side, hemispherical on the lower leaf side. In summer a cylindrical inner part containing a yellow larva separates from the rest of the swelling on the leaf and falls to the ground where it remain until the spring of the following year. Only one generation develops per year.

OCCURENCE: Szarkowszczyzna [Fiedorowiczowna, 1931], Oszmiana [Perepeczko-Baumanowa, 1935], rare [Petrov, 2010].

DISTRIBUTION: Eurosiberian.

Geocrypta galii (Loew, 1850)

BIOLOGY. Reddish-yellow larvae cause round bladder swellings on stems and ower stalks of Galium mollugo L., G. verum $\mathrm{L}$. and other species (Rubiaceae). The galls are solitary or gregarious and coalescent, their walls are fleshy, glossy, with a lateral opening. Inside each gall is one chamber. Several generations develop per year. Pupation and hibernation takes place in the soil.

OCCURENCE: Szarkowszczyzna [Fiedorowiczowna, 1931], Oszmiana [Perepeczko-Baumanowa, 1935].

DISTRIBUTION: Eurosiberian.

Giraudiella inclusa (Frauenfeld, 1862)

BIOLOGY. Solitary whitish or slightly pink coloured larvae produce corn-like, hard woody galls inside the stem of Phragmites australis (Cav.) Trin. (Poaceae). Two generations develop per year. Larvae pupate and also hibernate in the galls [Skuhravá, Skuhravý, 1981]. 
OCCURENCE: Berezinsky Biosphere Reserve [Carbonnelle, 2016], first record.

DISTRIBUTION: European.

Harmandiola cavernosa (Rübsaamen, 1889)

BIOLOGY. Solitary orange red larvae produce large, thick walled galls on the leaves of Populus tremula L. (Salicaceae). The globular gall develops on the upper leaf side; it partly extends to the underside where it has a slit-like opening. One generation develops per year. Larvae hibernate in the soil.

OCCURENCE: rare [Petrov, 2010].

DISTRIBUTION: Eurosiberian.

Harmandiola globuli (Rübsaamen, 1889)

BIOLOGY. A solitary red yellow larva produces small unilocular, globular, hard but thin walled gall on the upper surface of the leaf of Populus tremula L. (Salicaceae). The slit-like opening is on the lower surface. One generation develops per year. Larvae hibernate in the soil.

OCCURENCE: Grodno [Ostrowski, 1926], Szarkowszczyzna [Fiedorowiczowna, 1931], Oszmiana [PerepeczkoBaumanowa, 1935], without locality [Petrov, 2004, 2010].

DISTRIBUTION: Eurosiberian.

\section{Harmandiola populi (Rübsaamen, 1917)}

BIOLOGY. Solitary yellow larvae produce small, unilocular, globular, hard but thin-walled galls on the lower surface of the leaf of Populus tremula L. (Salicaceae), with the opening on the upper side. One generation develops per year. Hibernation takes place in the soil.

OCCURENCE: Grodno [Ostrowski, 1926], frequent [Petrov, 2010].

DISTRIBUTION: Eurosiberian.

\section{Harmandiola tremulae (Winnertz, 1853)}

Diplosis loewii Rübsaamen, 1892.

BIOLOGY. Solitary red larvae cause large, unilocular, globular, very hard and thick-walled galls on the upper surface of the leaf of Populus tremula L. (Salicaceae). The opening is on the lower side. One generation develops per year. Larvae hibernate in the soil.

OCCURENCE: Grodno [Ostrowski, 1926], Szarkowszczyzna [Fiedorowiczowna, 1931], Oszmiana [PerepeczkoBaumanowa, 1935], without locality [Petrov, 2004], frequent, outbreaks from time to time [Petrov, 2010].

DISTRIBUTION: Eurosiberian, occurring up to Kazakhstan.

Hybolasioptera fasciata (Kieffer, 1904)

Lasioptera cerealis, var. fasciata Kieffer, 1904

Syn.Hybolasioptera cerealis (Lindeman, 1881).

BIOLOGY. Larvae live in depressions of stems of Secale cereale L., Triticum aestivum L., Elymus repens (L.) Gould (Agropyron repens $(\mathrm{L}$.) $\mathrm{Pb}$ ) and other species and genera of Poaceae. Mamaeva and Mamaev (1981) gave this species among pests of agricultural plants.

OCCURENCE: Mogilev [Lindeman, 1881].

DISTRIBUTION: European.

\section{Iteomyia capreae (Winnertz, 1853)}

BIOLOGY. At first white, then orange, and at maturity red larvae produce small hemispherical galls on the leaves of Salix caprea L., S. aurita L. and their hybrids and relatives (Salicaceae). The circular ope-ning is on the lower surface of the leaf. Each gall contains one larva. When full-grown, larvae leave galls and drop to the soil where they hibernate. One generation develops per year.
OCCURENCE: Szarkowszczyzna [Fiedorowiczowna, 1931], Oszmiana [Perepeczko-Baumanowa, 1935], without locality [Petrov, 2004], frequent [Petrov, 2010].

DISTRIBUTION: Eurosiberian.

\section{Iteomyia major (Kieffer, 1898)}

BIOLOGY. Pale orange coloured larvae produce large irregular, plurilocular swellings of leaf veins on Salix caprea L. and $S$. cinerea L. (Salicaceae). The gall has many chambers with openings on the lower side. One generation develops per year. Larvae hibernate in the soil. 1931].

OCCURENCE: Szarkowszczyzna [Fiedorowiczowna,

\section{DISTRIBUTION: European.}

\section{Jaapiella veronicae (Vallot, 1827)}

BIOLOGY. Several orange coloured larvae develop in galls on growing tips of Veronica chamaedrys L. (Scrophulariaceae). The two terminal leaves are shell-like thickened, densely covered with white hair, pressed together, forming a cavity in which the larvae live and pupate in white cocoons. Several overlapping generations develop per year. Larvae hibernate in the soil where they pupate in the spring.

OCCURENCE: Grodno [Ostrowski, 1926], Szarkowszczyzna [Fiedorowiczowna, 1931], Oszmiana [PerepeczkoBaumanowa, 1935].

DISTRIBUTION: European.

\section{Jaapiella genisticola (F.Löw, 1877)}

BIOLOGY. First white, then pale rose coloured larvae cause galls at the growing tips of Genista tinctoria L. (Fabaceae). Terminal leaves are tufted, swollen, forming a yellowish hairy mass about the size of a hazel nut.

OCCURENCE: rare [Petrov, 2010].

DISTRIBUTION: Eurosiberian.

\section{Jaapiella vacciniorum (F.Löw, 1877)}

Dichelomyia vaccinii Rübsaamen, 1895

BIOLOGY. Red larvae develop among deformed leaves at the shoot tips of Vaccinium myrtillus $\mathrm{L}$.

(Ericaceae)

OCCURENCE: rare [Petrov, 2010].

DISTRIBUTION: European.

\section{Lasioptera francoisi (Kieffer, 1901)}

Lasioptera francoisi (Kieffer 1901).

Syn. Lasioptera niveocincta Kieffer, 1904.

BIOLOGY. Larvae cause flat spindle-shaped swellings on midribs and leaflets of Achillea millefolium L. (Asteraceae); each gall with only one larva.

OCCURENCE: Grodno [Ostrowski, 1926].

DISTRIBUTION: European.

\section{Lasioptera populnea Wachtl, 1883}

BIOLOGY. Orange larvae live as inquilines in galls of Contarinia populi (Rübs.) on leaves of Populus tremula L. (Salicaceae).

OCCURENCE: Grodno [Ostrowski, 1926].

DISTRIBUTION: Eurosiberian.

\section{Lasioptera rubi (Schrank, 1803)}

Lasioptera albipennis Meigen, 1804.

Lasioptera argyrosticta Meigen, 1830

BIOLOGY. Orange larvae develop gregariously in hard woody swellings on stems of Rubus idaeus L., R. caesius L. and other species of Rubus (Rosaceae). One generation de- 
velops per year. Pupation takes place in the gall. It is a minor but widespread pest of Rubus species [Darvas et al., 2000].

OCCURENCE: Grodno [Ostrowski, 1926], Oszmiana [Perepeczko-Baumanowa, 1935], without locality [Petrov, 2004], pest in orchards [Petrov, 2010]; Berezinsky Biosphere Reserve [Carbonnelle, 2016]

DISTRIBUTION: Eurosiberian.

Macrodiplosis pustularis (Bremi, 1847)

Diplosis dryobia F.Löw, 1877.

BIOLOGY. First white, later red-yellow larvae cause galls on leaf margins of Quercus robur L. and Q. petraea (Matt.) Liebel (Fagaceae). The marginal leaf lobe is a little thickened and folded downwards forming a cavity for development of larvae. Only one generation develops per year. Larvae leave the galls and hibernate in the soil where they pupate in the spring of the next year.

OCCURENCE: Grodno [Ostrowski, 1926], Szarkowszczyzna [Fiedorowiczowna, 1931], rare [Petrov, 2010].

DISTRIBUTION: European, up to Kazakhstan.

Macrodiplosis roboris (Hardy, 1854)

Macrodiplosis volvens Kieffer, 1895.

BIOLOGY. First whitish, later orange-yellow larvae cause galls on leaf margins of Quercus robur $\mathrm{L}$. and $Q$. petraea (Matt.) Liebel (Fagaceae). The part of the leaf between two lobes is rolled upwards forming inside a chamber for development of larvae. Only one generation develops per year. Larvae leave the galls and hibernate in the soil where they pupate in the spring of the next year.

OCCURENCE: Grodno [Ostrowski, 1926], Szarkowszczyzna [Fiedorowiczowna, 1931], Oszmiana [PerepeczkoBaumanowa, 1935], rare [Petrov, 2010].

DISTRIBUTION: European, occurring up to Kazakhstan.

Macrolabis chamaecytisicola Fedotova, 2004

BIOLOGY. Pink larvae develop in folded leaflets at vegetative tips of Chamaecytisus ruthenicus (Fisch. ex Woloszcz.) Klásk. (Fabaceae). This species was discovered and described by Fedotova (2004) several years ago on the basis of material collected in the Zhiguli Nature Reserve in the Middle Volga Region in southern Russia.

OCCURENCE: eastern and southern part of Belarus [Petrov 2010, incorrectly identified as Dasineura cytisi Kieffer, 1909].

DISTRIBUTION: European.

Macrolabis lamii Rübsaamen, 1915

BIOLOGY. Whitish larvae live in leaf galls at stem tips of Lamium album L. (Lamiaceae). Two generations develop per year. Larvae pupate and hibernate in the soil.

OCCURENCE: Grodno [Ostrowski, 1926].

DISTRIBUTION: European.

Mayetiola destructor (Say, 1817)

Mayetiola secalis Bollow, 1955.

BIOLOGY. White larvae cause swellings on the lower part of the stem on Triticum aestivum L. (T. vulgare Vill.), Secale cereale L., Hordeum vulgare L. and occasionally also on various species of weed grasses (Poaceae). There are usually two generations per year. Larvae hibernate in puparia on plants and pupate there in the next spring. It is a minor pest in Europe but the main pest of cereals in North America [Skuhravá et al., 1984a; Darvas et al., 2000].

OCCURENCE: present in Belarus but locality not given [Trepashko et al., 2012].
DISTRIBUTION: Cosmopolitan originating from Palaearctic, widespread in Europe, western Asia, Morocco to Tunis, immigrant in Nearctic wherever wheat is grown; also New Zealand.

Neomikiella lychnidis (Vallot, 1827)

Cecidomyia lychnidis Heyden, 1861.

BIOLOGY. Whitish larvae develop in large, densely haired leaf bud galls on stems of Silene pratensis (Rafn.) Godr. (Melandrium album (Mill.) Garcke) (Caryophyllaceae). 931].

OCCURENCE: Szarkowszczyzna [Fiedorowiczowna,

DISTRIBUTION: European, Sub-Mediterranean.

Obolodiplosis robiniae (Haldeman, 1847)

BIOLOGY. White larvae cause galls on leaflets of Robinia pseudoacacia L. (Fabaceae). The margin of attacked leaflets is swollen and rolled downwards. Obolodiplosis robiniae is native to the Northeastern part of the USA. It has been imported from the USA into Europe, probably with plant material. The galls appeared suddenly in north-eastern Italy (Paese, Treviso Province) in July 2003 but the source of infestation remained unknown [Duso, Skuhravá, 2003]. It was distributed throughout Europe very quickly [Skuhravá et al., 2007; Skuhravá et al., 2010].

OCCURENCE: this species was recorded for the first time in the Gomel Region in the year 2009 [Petrov, 2010].

DISTRIBUTION: originally from the Nearctic, in Europe it is classed as an invasive species.

Oligotrophus juniperinus (Linnaeus, 1758)

BIOLOGY. Single orange coloured larvae cause galls on Juniperus communis L. (Cupressaceae). The galls are slender, about $12 \mathrm{~mm}$ long, involving more than two verticils of needles. Outer needles of the gall have recurved tips. One generation develops per year. Larvae pupate in the gall. According to Harris et al. [2006], the life cycle may last two years.

OCCURENCE: frequent [Petrov, 2010], Berezinsky Biosphere Reserve, [Carbonnelle, 2016].

DISTRIBUTION: European.

\section{Oligotrophus panteli Kieffer, 1898}

Fig. 2

BIOLOGY. Orange larva lives solitary in a gall on Juniperus communis L. (Cupressaceae). The gall has a bulbous base and pointed apex. One generation develops per year. Larvae pupate in the gall. According to Harris et al. [2006], the life cycle may last two years.

OCCURENCE: frequent [Petrov, 2010], Berezinsky Biosphere Reserve, [Carbonnelle, 2016]

DISTRIBUTION: European, up to Africa.

\section{Plemeliella abietina Seitner, 1908}

BIOLOGY. Yellow or pink-yellow larvae live in developing seed in the cones of Picea abies (L.) Karsten (= Picea excelsa (Lam.) Link.) (Pinaceae). Infested seeds are slightly sunken, deformed and discoloured. The development lasts three years. Larvae feed by sucking sap from the seed. Larvae hibernate in the seed. It is a minor pest [Skuhravá, Roques, 2000].

OCCURENCE: without locality [Tigabu et al. 2004].

DISTRIBUTION: European.

Rabdophaga dubiosa (Kieffer, 1913)

Rhabdophaga dubia Kieffer, 1891.

BIOLOGY. Yellowish-red larvae cause swellings on twigs of Salix aurita L., S. cinerea L. and S. alba L. (Salicaceae). 


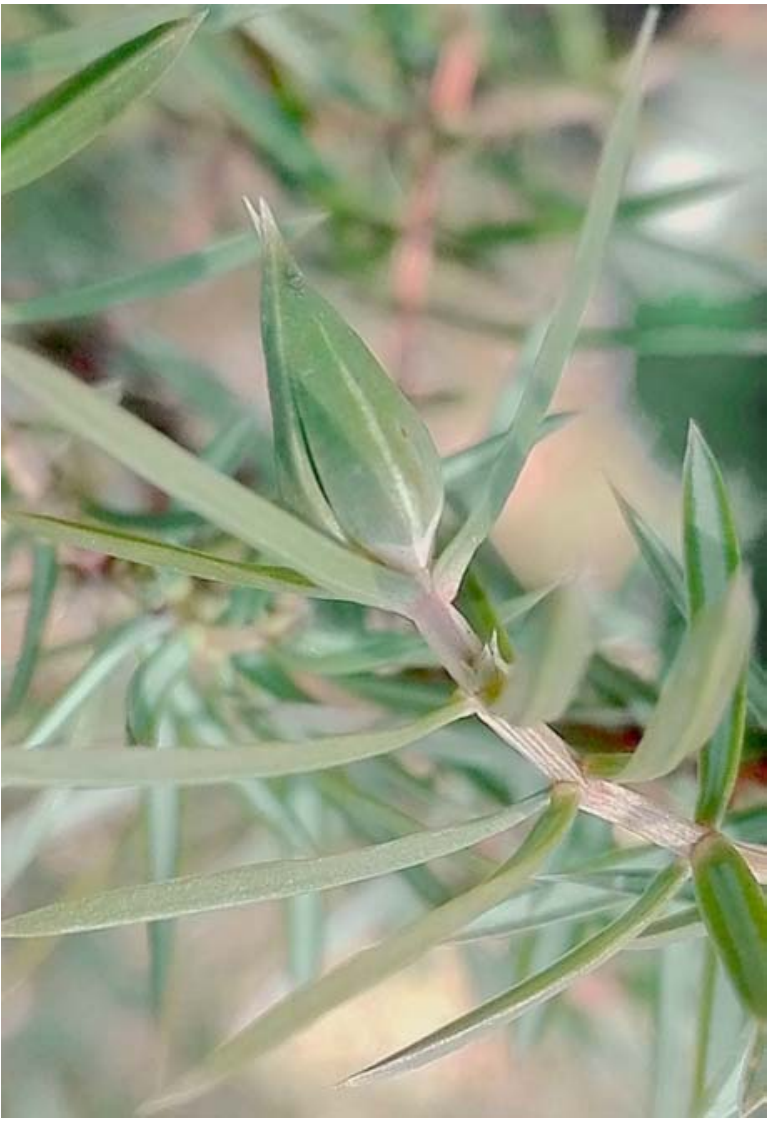

Fig. 2. Gall of Oligotrophus panteli on Juniperus communis. Berezinsky Biosphere Reserve, April 2016 (photo by Sébastien Carbonnelle).

Рис. 2. Галл Oligotrophus panteli на можжевельнике Juniperus communis. Березинский биосферный заповедник, апрель 2016 (фото Себастьяна Карбонелле).

The gall is $15-20 \mathrm{~mm}$ long, $8-12 \mathrm{~mm}$ broad, inside with many lengthwise chambers each containing one larva. One generation develops per year. Larvae hibernate in the galls. 1931]

OCCURENCE: Szarkowszczyzna [Fiedorowiczowna,

\section{DISTRIBUTION: European.}

Rabdophaga heterobia (Loew, 1850)

BIOLOGY. Several orange-red larvae cause galls on Salix triandra L. (=S. amygdalina L.) (Salicaceae). Two generations develop per year. Larvae of the hibernating generation develop in deformed and swollen male catkins, where they also pupate. Larvae of the summer generation develop in small rosettes of haired leaves at the extremities of the shoots or in swollen lateral buds or lateral rosettes. Barnes [1949] made extensive experiments with host plant range and found that $R$. heterobia (Loew) is specically associated with Salix triandra. Similar galls on Salix repens, S. purpurea and other species of Salix cited in the literature and summarized by Houard [1908-1909] as food plants are caused by another species of the genus Rabdophaga.

OCCURENCE: Szarkowszczyzna [Fiedorowiczowna, 1931], rare, sometimes frequent [Petrov, 2010], Berezinsky Biosphere Reserve [Carbonnelle, 2016].

DISTRIBUTION: Eurosiberian, up to Kazakhstan.
Rabdophaga iteobia (Kieffer, 1890)

BIOLOGY. Orange larvae live gregariously among the leaves, densely covered with white hairs, forming a loose rosette gall at the top of the branch of Salix caprea L. (Salicaceae). The leaves of the shortened internodes are clustered, abnormally and white haired. One generation develops per year. Larvae hibernate in the galls.

OCCURENCE: Szarkowszczyzna [Fiedorowiczowna, 1931].

DISTRIBUTION: Eurosiberian.

Rabdophaga nervorum (Kieffer, 1895)

Dichelomyia noduli Rübsaamen, 1895.

BIOLOGY. Red-yellow larva develops in spindle-shaped swelling of the midvein on the leaf of Salix caprea L. and $S$. aurita L. (Salicaceae). Each swelling contains only one larva. It pupates in the gall.

OCCURENCE: Oszmiana [Perepeczko-Baumanowa, 1935].

DISTRIBUTION: European.

Rabdophaga repenticola (Stelter, 1964)

BIOLOGY. Larvae cause leaf bud galls on Salix repens L. and S. repens L. subsp. rosmarinifolia (L.) Èelak. (Salicaceae). One generation develops per year. Larvae hibernate in the galls.

OCCURENCE: Berezinsky Biosphere Reserve, Carbonnelle 2016, first record.

DISTRIBUTION: European.

NOTE: It is a valid species, not a synonym of $R$. clavifex (Kieffer) as it is given in Gagné [2004, 2010].

\section{Rabdophaga rosaria (Loew, 1850)}

Cecidomyia cinerearum Hardy, 1850

BIOLOGY. A single orange red larva causes a large rosette leaf gall on terminal or lateral buds of Salix alba L., $S$. caprea L., S. cinerea L., S. aurita L. and related species of Salix (Salicaceae). One generation develops per year. Hibernation and pupation takes place in the gall.

OCCURENCE: Grodno [Ostrowski, 1926], Szarkowszczyzna [Fiedorowiczowna, 1931], Oszmiana [Perepeczko-Baumanowa, 1935], without locality [Petrov, 2004], frequent, outbreaks from time to time [Petrov, 2010], Berezinsky Biosphere Reserve [Carbonnelle, 2016].

DISTRIBUTION: Eurosiberian.

Rabdophaga salicis (Schrank, 1803)

BIOLOGY. Orange coloured larvae cause obvious, woody, fusiform or spherical, plurilocular swel-lings on the branches of Salix cinerea L., S. aurita L. and S. caprea L. (Salicaceae). One generation develops per year. Larvae hibernate and pupate in the gall.

OCCURENCE: Oszmiana [Perepeczko-Baumanowa, 1935], frequent [Petrov, 2010], Berezinsky Biosphere Reserve [Carbonnelle, 2016].

DISTRIBUTION: Eurosiberian.

Resseliella betulicola (Kieffer, 1889)

Plemeliella betulicola (Kieffer, 1889).

BIOLOGY. Yellowish-white larvae develop among the youngest terminal leaves on the vegetative tips of Betula pubescens Ehrh. and B. Pendula Roth (Betulaceae). Usually only one generation develops per year. Fully developed larvae leave gallsand fall to the soil where they hibernate until spring of the following year. 
OCCURENCE: frequent, outbreaks from time to time on young trees [Petrov, 2010].

DISTRIBUTION: Eurosiberian.

Rhopalomyia artemisiae (Bouché, 1834)

BIOLOGY. Orange coloured larvae cause large globular galls at the tips or in axils of Artemisia campestris L. and $A$. scoparia Wk (Asteraceae). One or several chambers are inside one gall, each with only one larva.

OCCURENCE: without locality [Petrov, 2004].

DISTRIBUTION: European.

Semudobia betulae (Winnertz, 1853)

BIOLOGY. A single orange coloured larva develops in swollen fruit in catkins of Betula pubescens Ehrh. and B. pendula Roth. (Betulaceae). The attacked seed is swollen, with a small window-pit (for future emergence), and the wings of the fruit are reduced. One generation develops per year. Larvae hibernate in the gall where they pupate in the spring.

OCCURENCE: Berezinsky Biosphere Reserve [Carbonnelle, 2016], first record.

DISTRIBUTION: Eurosiberian, immigrant in North America.

\section{Semudobia skuhravae Roskam, 1977}

BIOLOGY. Larvae cause small galls which are joined to the spindle of catkins of Betula pendula L. (Betulaceae). The life cycle is similar to the cycle of Semudobia betulae (Winnertz).

OCCURENCE: Berezinsky Biosphere Reserve, [Carbonnelle, 2016], first record.

DISTRIBUTION: Eurosiberian and Holarctic.

Semudobia tarda Roskam, 1977

BIOLOGY. A single orange coloured larva develops in swollen fruit in catkins of Betula pendula Roth. and B. pubescens Ehrh. (Betulaceae). The fruit is button-like, swollen and its wings are completely or nearly completely reduced, the window-pit is rather indistinct. The life cycle is similar to the cycle of Semudobia betulae (Winnertz).

OCCURENCE: Berezinsky Biosphere Reserve [Carbonnelle, 2016], first record.

DISTRIBUTION: Eurosiberian, immigrant in North America.

Thecodiplosis brachyntera (Schwägrichen, 1835)

BIOLOGY. One to several orange red larvae cause galls at the base of the pair of needles of Pinus sylvestris L. and other species of the genus Pinus (Pinaceae). Attacked pine needles are abnormally short and discoloured. One generation develops per year. Pupation takes place either in galls or in the soil. It is a major pest of pine in Central Europe. Several outbreaks were observed during the $19^{\text {th }}$ and $20^{\text {th }}$ centuries [Skuhravá, Roques, 2000; Skuhravý, 1991].

OCCURENCE: serious pest [Petrov, 2010].

DISTRIBUTION: Eurosiberian.

Wachtliella persicariae (Linné, 1767)

BIOLOGY. Whitish-orange larvae produce galls in the form of rolled leaf margins on Polygonum amphibium L. (Polygonaceae). Each gall contains several larvae that pupate here in a white cocoon. Several generations develop per year. 1931].

OCCURENCE: Szarkowszczyzna [Fiedorowiczowna,

DISTRIBUTION: European, occurring up to Caucasus.

\section{Evaluation of results}

\section{Species number}

The gall midge fauna of Belarus including 73 known species may be classed as little or only moderately known in comparison with the species richness of gall midges in adjacent countries where comparable data are available: 225 species in Lithuania, of which 164 species belong to the subfamily Cecidomyiinae [Pakalniškis et al., 2000]; 300 species in Ukraine, of which 172 species belong to the subfamily Cecidomyiinae [Skuhravá, Skuhravý, unpublished data]; 506 species in Latvia: of which 265 species belong to the subfamily Cecidomyiinae [Spungis, 2003]; 463 species in Poland, of which 369 species belong to the subfamily Cecidomyiinae [Skuhravá et al., 2008]; 650 species in Russia - European part: of which 400 species belong to the subfamily Cecidomyiinae [Skuhravá, Skuhravý, unpublished data].

It is necessary to note that the species numbers of the country under study are influenced by several factors, mainly by abiotic factors, i.e. by geographic and altitudinal position of the area under study that are associated with changing climatic variables including sunshine, temperature and rainfall; by the size of the area under study; by biotic factors, i.e. mainly by the type of vegetation cover and composition of natural vegetation (and incidence of natural enemies); and by anthropic factors, involving various human activities and by intensity of investigations. Results of gall midge species numbers in the area under study are affected also by the number of investigations and by selection of suitable sites for collection of gall midges. More investigations and more samples usually result in increased species numbers, new records and also discovery of new species. It is necessary also to emphasize the importance of the researchers, their ability, experience, knowledge and enthusiasm that make it possible to discover gradually additional gall midge species and hidden factors influencing gall midge species richness [Skuhravá, Skuhravý, 2010].

We suppose that further investigations of gall midges in various parts of Belarus will reveal other species of gall midges. We expect that the recorded gall midge fauna should increase to 200 or to 250 species in future years if intensive investigations will be carried out.

\section{Species density}

Species density refers to the number of species per unit area. This method enables comparison of species numbers occurring in various parts of the study areas as was shown by Skuhravá and Skuhravý [2010].

Species density for gall midge species on $1000 \mathrm{~km}^{2}$ may be calculated using the formula of MacArthur and Wilson [1967]: $\mathbf{S}=\mathbf{x} / \mathbf{a}^{0.25}$ where $\mathbf{S}$ is the number of species per area of $1000 \mathrm{~km}^{2}, \mathbf{x}$ is the number of gall midge species found in the country and a is the whole area of the country expressed in $1000 \mathrm{~km}^{2}$. We calculated the species density for Belarus and adjacent countries (Table 1). We arranged these countries according to their country areas, added the species numbers of the subfamily Cecidomyiinae obtained during investigations by researchers in the country and 
calculated the species density for each country according to formula MacArthur and Wilson [1967].

Belarus has the lowest species density - only 19 species occur in the area of $1000 \mathrm{~km}^{2}$, although it has a relatively large country area $\left(207,600 \mathrm{~km}^{2}\right)$ and belongs in the middle position from the point of view of the area size among 6 adjacent countries in Eastern Europe. The highest species density (94.5) has been recorded in Poland where intensive investigations of gall midges have been undertaken by many researchers during the course of the twentieth century. It is narrowly followed by Latvia (94.1) where intensive investigations have been undertaken in the course of the end of the twentieth and at the beginning of twenty first centuries [Spungis, 2003]. It is interesting to note that Russia (European part) from which the highest number of species of gall midges (400 species) is known, occupies the middle position in species density (50.6). It is connected with the very large country area of the European part of Russia occupying $3,960,000 \mathrm{~km}^{2}$.

It is possible to conclude from all these facts that the most important factor for improvement of the level of knowledge is to carry out intensive searching for gall midges in various parts of the country.

\section{Zoogeography}

The gall midge fauna of Belarus may be divided into two groups on the basis of zoogeographical analysis, according to the distribution of gall midge species in the Palaearctic region: Euro-Siberian and European species.

Euro-Siberian species inhabit the Euro-Siberian subregion of the Palaearctic region. They have centres of origin in Europe where they occur, usually abundantly, and extend at least to Western Siberia, with some of them reaching to Central Siberia and only a few reaching to Eastern Siberia and to the most eastern part of the Palaearctic Region, to the Far East. They may also reach marginal parts of Asia. In Belarus 42 gall midge species $(57 \%)$ belong in this group, for example Contarinia coryli larvae of which develop in swollen catkins of Corylus avellana occupies a large distribution area from Europe across Siberia up to China. Some EuroSiberian species may secondarily occur in the Nearctic, for example Contarinia pyrivora and Dasineura pyri, both associated with Pyrus communis.

Mayetiola destructor, a serious pest of cereals, larvae of which cause galls on stems, originated from the Palaearctic, and is classed as cosmopolitan. It is widespread in Europe, western Asia, and in North Africa from Morocco to Tunis, and it is an immigrant in the Nearctic Region wherever wheat is grown, and occurs also in New Zealand.

European species are associated with European host plant species that have centres of origin in Europe. They may reach marginal parts of Asia or Africa. In Belarus 30 gall midge species (41\%) belong in this group, for example Dasineura fraxini, larvae of which cause swellings of the mid-vein on leaflets of Fraxinus excelsior, occupies a large distribution area in Europe and occurs also in Algeria in North Africa.
Table 1. Species density of gall midge species in Belarus and comparison with species density in adjacent countries.

Таблица 1. Плотность видов галлиц в Беларуси по сравнению с плотностью в соседних странах.

\begin{tabular}{|l|c|c|c}
\hline \multicolumn{1}{|c|}{ country } & area $\left.\mathbf{( k m}^{\mathbf{2}}\right)$ & $\begin{array}{c}\text { number } \\
\text { of species }\end{array}$ & $\begin{array}{c}\text { species density } \\
\text { per 1000 } \mathbf{k m}^{2}\end{array}$ \\
\hline Latvia & 64,589 & 264 & 94.1 \\
\hline Lithuania & 65,200 & 164 & 57.7 \\
\hline Belarus & $\mathbf{2 0 7 , 6 0 0}$ & $\mathbf{7 3}$ & $\mathbf{1 9 , 2}$ \\
\hline Poland & 312,685 & 397 & 94.5 \\
\hline Ukraine & 603,700 & 166 & 33.8 \\
\hline $\begin{array}{l}\text { Russia, } \\
\text { European part }\end{array}$ & $3,960,000$ & 400 & 50.6 \\
\hline
\end{tabular}

Nearctic species are associated with Nearctic host plant species and are alien species introduced to the Eurasian continent. It is the case of one species, Obolodioplosis robiniae, which is now widespread on the European continent on the widely cultivated and naturalized Robinia pseudoacacia.

\section{Plant-insect interactions}

Gall midges found in Belarus are associated with 58 host plant species belonging to 25 plant families (Table 2). 32 species of host plants are trees and shrubs and 26 species are herbaceous plants. 16 gall midge species are associated with the family Salicaceae, of them 7 species with Populus tremula and 9 species with various species of the genus Salix; 8 gall midge species with the family Rosaceae (Malus, Rubus, Pyrus, Filipendula), 7 species with Betulaceae (Betula, Alnus), 4 gall midge species with Fabaceae and 3 with Asteraceae. Other plant families are hosting only one or two species of gall midges. Populus tremula is the host plant with the highest number of associated species of gall midges: Contarinia petioli, Dasineura populeti, Harmandiola cavernosa, H. globuli, H. populi, H. tremulae and Lasioptera populnea.

\section{Economic importance}

The gall midges that occur on cultivated plants in fields, in gardens, fruit orchards and in forests in Belarus do not have such importance as they have in central and southern Europe. Usually their occurrence is not so high and their importance cannot be compared with the same gall midge species in Europe, where they sometimes occur as serious pests.

Larvae of gall midges may develop in flower and leaf buds, stems, leaves, fruits and pods or other organs of host plants that are important in agriculture and in forestry. The importance of some gall midge species can fluctuate over the years from minimal up to outbreak.

In Belarus 7 species of gall midges are associated with agricultural plants and could cause damage if they multiply too much. Some of them may occur abruptly and cause harm to their host plant for a short time and then their importance decreases to a minimum. The importance of other gall midges injurious to agricultural crops decreased but their larvae may remain hidden in the soil in fields and it is necessary to be watchful. It is 
Table 2. Host plants and associated species of gall midges. Таблица 2. Растения-хозяева и связанные с ними виды галлиц.

\begin{tabular}{|c|c|}
\hline Host plant species & Gall midge species \\
\hline Achillea millefolium & Lasioptera francoisi \\
\hline Alnus glutinosa, A. incana & Dasineura tortilis \\
\hline Artemisia campestris, A. scoparia & Rhopalomyia artemisiae \\
\hline Betula pubescens, $B$. pendula & Anisostephus betulinus, Resseliella betulicola, Semudobia betulae, S. skuhravae, S. tarda \\
\hline Caragana arborescens & Dasineura sibirica \\
\hline Carpinus betulus & Contarinia carpini \\
\hline Chamaecytisus ruthenicus & Macrolabis chamaecytisicola \\
\hline Corylus avellana & Contarinia coryli \\
\hline Daphne mezereum & Dasineura daphnes \\
\hline Epilobium angustifolium & Dasineura kiefferiana \\
\hline Filipendula ulmaria & Dasineura ulmaria \\
\hline Fraxinus excelsior & Dasineura fraxini \\
\hline Galium mollugo, G. verum & Geocrypta galii \\
\hline Galium uliginosum & Dasineura galiicola \\
\hline Genista tinctoria & Jaapiella genisticola \\
\hline Hypericum perforatum & Dasineura hyperici \\
\hline Hypericum humifusum & Dasineura serotina \\
\hline Juniperus communis & Oligotrophus juniperinus, O. panteli \\
\hline Lamium album & Macrolabis lamii \\
\hline Malus domestica & Dasineura mali \\
\hline Phragmites australis & Giraudiella inclusa \\
\hline Picea abies & Plemeliella abietina \\
\hline Pinus sylvestris & Thecodiplosis brachyntera \\
\hline Polygonum amphibium & Wachtliella persicariae \\
\hline Populus tremula & $\begin{array}{l}\text { Contarinia petioli, Dasineura populeti, Harmandiola cavernosa, H. globuli, H. populi, } \\
\text { H. tremulae, Lasioptera populnea }\end{array}$ \\
\hline Prunus spinosa & Dasineura sodalis, Dasineura tortrix \\
\hline Pteridium aquilinum & Dasineura pteridicola \\
\hline Pyrus communis & Contarinia pyrivora, Dasineura pyri \\
\hline Quercus robur, Q. petraea & Macrodiplosis pustularis, $M$. roboris \\
\hline Ribes nigrum & Dasineura tetensi \\
\hline Robinia pseudoacacia & Obolodiplosis robiniae \\
\hline Rorippa palustris & Dasineura sisymbrii \\
\hline Rosa sp. & Dasineura rosae \\
\hline Rubus idaeus, $R$. caesius & Lasioptera rubi \\
\hline Salix alba & Rabdophaga rosaria \\
\hline Salix aurita & Rabdophaga dubiosa, $R$. rosaria \\
\hline Salix caprea & Iteomyia capreae, I. major, Rabdophaga iteobia, $R$. nervorum, $R$. rosaria \\
\hline Salix cinerea & Rabdophaga salicis, $R$. rosaria \\
\hline Salix repens & Rabdophaga repenticola \\
\hline Salix triandra & Rabdophaga heterobia \\
\hline Secale cereale & Hybolasioptera fasciata \\
\hline Silene pratensis & Neomikiella lychnidis \\
\hline Sonchus oleraceus & Cystiphora sonchi \\
\hline Tilia cordata, T. platyphyllus & Contarinia tiliarum, Dasineura tiliae, Didymomyia tiliacea \\
\hline Triticum aestivum & Mayetiola destructor \\
\hline Urtica dioica & Dasineura dioicae, Dasineura urticae \\
\hline Vaccinium myrtillus & Jaapiella vacciniorum \\
\hline Vaccinium vitis-idaea & Dasineura vitisideae \\
\hline Veronica chamaedrys & Jaapiella veronicae \\
\hline Viola reichenbachiana & Dasineura affinis \\
\hline Viola tricolor & Dasineura violae \\
\hline
\end{tabular}

necessary to evaluate all these species as potential pests.

First of all is Mayetiola destructor, larvae of which damage stems of cereals; Contarinia pyrivora, larvae of which develop inside fruits of Pyrus communis, and Dasineura pyri, attacking young developing leaves mainly in nurseries; Dasineura mali, which is a serious pest of young apple trees and scions in orchards and in nurseries ; Dasineura tetensi attacking young leaves of
Ribes nigrum; Dasineura tortrix, damaging young leaves of various species of cultivated Prunus; Lasioptera rubi, damaging stems of cultivated Rubus.

ACKNOWLEDGEMENTS. We thank Dr. Alexander Lukashuk for his invitation to write an article about gall midges in Belarus, and Dr. Keith Murray Harris (Ripley, Woking, Surrey, England) for valuable comments on the manuscript and for improvements of the English text. 


\section{References}

Barnes H.F. 1949. Gall Midges of Economic Importance. Vol.6. Gall midges of Miscellaneous Crops. London: Crosby Lockwood \& Son Ltd. 229 pp.

Barnes H.F. 1951. Gall Midges of Economic Importance. Vol.5. Gall midges of Trees. London: Crosby Lockwood \& Son LTD. 270 pp.

Buhr H. 1964-1965. Bestimmungstabellen der Gallen (Zoo- und Phytocecidien) an Pflanzen Mittel- und Nordeuropas. Gustav Fischer Verlag. Jena. $1572 \mathrm{~S}$.

Darvas B., Skuhravá M., Andersen A. 2000. Agricultural dipteran pests of the Palaearctic region // Papp L., Darvas B. (eds.). Contributions to a Manual of Palaearctic Diptera. Vol.1. General and Applied Dipterology. Budapest: Science Herald. P.565-650.

Duso C., Skuhravá M. 2003. First record of Obolodiplosis robiniae (Haldeman) (Diptera Cecidomyiidae) galling leaves of Robinia pseudoacacia L. (Fabaceae) in Italy and Europe // Frustula Entomologica Vol.25 (2002). P.117-122.

Gagné R.J., Jaschof M. 2017 A Catalog of the Cecidomyiidae (Diptera) of the World. Fourth Edition. Digital. $762 \mathrm{pp}$.

Harris K.M. 1966. Gall midge genera of economic importance (Diptera, Cecidomyiidae). Part 1. Introduction and subfamily Cecidomyiinae; supertribe Cecidomyiidi // Transactions of the Royal Entomological Society of London. Vol.118. P.313-358.

Harris K.M. 1973. Aphidophagous Cecidomyiidae (Diptera): taxonomy, biology and assessments of field populations. // Bulletin of Entomological Research. Vol.63. P.305-325.

Harris K.M., Sato S., Uechi N., Yukawa J. 2006. Redefinition of Oligotrophus (Diptera: Cecidomyiidae) based on morphological and molecular attributes of species from galls on Juniperus (Cupressaceae) in Britain and Japan // Entomological Science. Vol.9. P.411-421

Houard C 1908-1909. Les Zoocécidies des Plantes d'Europe et du Bassin de la Méditerranée. Vols1-2. Paris. A. Hermann et Fils, $1247 \mathrm{pp}$.

Fedotova Z.A. 2004. [New species of gall midges from the genus Macrolabis Kieffer (Diptera, Cecidomyiidae) from Kazakhstan and Rossia] // Entomologicheskoe Obozrenie. Vol.83. No.3. P.718-733 [in Russian].

Fiedorowiczowna Z. 1931. Zoocecidia na roslinach zebranych w powiecie dzisnienskim i braslawskim Ziemi Wilenskej // Práce Towarzystwa przyjaciól nauk w Wilne. Vol.6. P.25-39.

Jaschhof M., Jaschhof C. 2009. The Wood Midges (Diptera: Cecidomyiidae: Lestremiinae) of Fennoscandia and Denmark // Studia Dipterologica. Suppl.18. 333 pp.

Kieffer J.J. 1909. Contributions à la connaissance des insectes gallicoles // Bulletin de la Société d'Histoire Naturelle de Metz. Ser.3. No.2. P.1-35.

Koltun N.E., Meleshko N.I. 1994. [Predators of the green apple aphid (Aphis pomi De Geer) and their effectiveness in apple nurseries in Belarus] // Vesci Akademii Agrarnych navuk Belarusi. Vol.4. P.57-59 [in Russian].

Lindeman K. 1880. Zwei neue, dem Getreide schädliche Insekten Russlands // Byulleten Moskovskoe Obshchestvo Ispytatelei Prirody. Vol.55. P.126-138.

Lindeman K. 1881. Ueber Eurytoma (Isosoma) hordei, Eurytoma albinervis, Lasioptera (Cecidomyia) cerealis und ihre Feinde Byulleten Moskovskoe Obshchestvo Ispytatelei Prirody. Vol.55 (1880). P.378-389.

Mac Arthur R.H., Wilson E.O. 1967. Island Biogeography. Princeton. Princeton University Press. 203 pp.

Mamaev B.M. 1962. [Gall midges, their biology and economical significance]. Moskva: Izdatelstvo AN SSSR. 71 pp. [in Russian]

Mamaev B.M., Krivosheina N.P. 1993. The Larvae of Gall Midges (Diptera, Cecidomyiidae). Comparative morphology, biology, keys. Translation of the publication: Lichinki gallits (Diptera, Cecidomiidae). Moscow: Nauka. 1965. Translated by J.H. Wieffering. Edited by J.C. Roskam. Rotterdam, Brookfield: A.A. Balkema. 293 pp.

Mamaeva Ch.P., Mamaev B.M. 1981. [6.Fam. Cecidomyiidae Gall Midges] // Nasekomyje i kleshchi — vrediteli selskokhozyaystvennych kultur. Vol.4. Hymenoptera and Diptera. Leningrad, Izdatelstvo Nauka. P.68-98 [in Russian]
Möhn E. 1955. Beiträge zur Systematik der Larven Itonididae (Cecidomyiidae, Diptera). 1. Teil: Porricondylinae und Itonidinae Mitteleuropas // Zoologica. Stuttgart. Bd.38. Hf.105. S.1-247.

Ostrowski S. 1926. Narosla (cecidia) zebrane na roslinach w okolicach Wilna i Grodna. Les Cécidies trouvées sur les plantes des environs de Wilno et de Grodno // Kosmos. Vol.51. P.62-74.

Pakalniškis S., Rimšaité J., Sprangauskaite-Bernotiene R., Butautaite R., Podenas S. 2000. Checklist of Lithuanian Diptera. (Cecidomyiidae, P.20-27) // Acta Zool. Lithuanica Vol.10. No.1. P.3-58.

Perepeczko-Baumanowa J. 1935. Zoocecidia zobrane w Oszmianie i najblizszych okolicach (zoocecidii Oszmiany, Belarus) // Práce Towarzystwa przyjaciól nauk w Wilne. Vol.9. P.239-261.

Petrov D.L. 2004. Common species of teratogenic insects in Belarus // Vestnik Belorusskogo-Gossudarskogo Universiteta. Ser.2. P.63-68.

Petrov D.L. 2010. Dendrofilnye galloobrazujuschschie dvukrylye (Insecta: Diptera) fauny Belorusi // Vestnik Belorusskogo-Gossudarskogo Universiteta. Ser.2. P.31-35.

Skuhravá M. 1986. Family: Cecidomyiidae // Soós Á., Papp L. (eds.). Catalogue of Palaearctic Diptera. Vol.4. Hungarian Academy of Sciences, Budapest: Akadémiai Kiadó and Amsterdam: Elsevier. P.72-297.

Skuhravá M. 1989. Taxonomic changes and records in Palaearctic Cecidomyiidae (Diptera) // Acta Entomologica Bohemoslovaca. Vol.86. P.202-233.

Skuhravá M. 1997. Cecidomyiidae // Papp L., Darvas B. (eds.). Contributions to a Manual of Palaearctic Diptera (with special reference to flies of economic importance). Vol.2. Nematocera and Lower Brachycera. Budapest: Science Herald. P.71-204.

Skuhravá M. 2006. Species richness of gall midges (Diptera: Cecidomyiidae) in the main biogeographical regions of the world // Acta Societatis Zoologicae Bohemicae. Vol.69. P.327-372.

Skuhravá M., Martinez M., Roques A. 2010. Chapter 10. Diptera. P.553-602 // Roques A., Kenis M., Lees D., Lopez-Vaamonde C., Rabitsch W., Rasplus J.Y., Roy B. (eds). Alien Terrestrial Arthropods of Europe. BioRisk Vol.4 (Special Issue). 1020 pp. Available: http://pensoftonline.net/biorisk/index.php/journal

Skuhravá M., Roques A. 2000. Palaearctic dipteran forest pests // Papp L., Darvas B. (eds.). Contributions to a Manual of Palaearctic Diptera. Vol.1. General and Applied Dipterology. Budapest. Science Herald. P.651-692.

Skuhravá M., Skuhravý V. 2010. Species richness of gall midges (Diptera, Cecidomyiidae) in Europe (West Palaearctic): biogeography and coevolution with host plants // Acta Societatis Zoologicae Bohemicae Vol.73 (2009). P.87-156.

Skuhravá M., Skuhravý V., Brewer J.W. 1984a. Biology of gall midges // Ananthakrishnan T.N. (ed.). Biology of Gall Insects. Oxford + IBH Publishing Company, New Delhi, Bombay, Calcutta. P.169-222.

Skuhravá M., Skuhravý V., Brewer J.W. 1984b. The distribution and long-term changes in population dynamics of gall midges $(\mathrm{Ce}-$ cidomyiidae, Diptera) on cereals in Europe // Cecidologia Internationale. Vol.5. Nos1-2. P.1-5.

Skuhravá M., Skuhravý V., Csóka G. 2007. The invasive spread of the gall midge Obolodiplosis robiniae in Europe // Cecidology. Vol.22. P.84-90, 70-71 (figs).

Skuhravá M., Skuhravý V., Skrzypczyńska M., Szadziewski R. 2008. Gall midges (Cecidomyiidae, Diptera) of Poland. Pryszczarki (Cecidomyiidae, Diptera) Polski // Annals of the Upper Silesian Museum (Entomology). Vol.16. P.5-160.

Skuhravý V. 1991. The needle-shortening gall midge Thecodiplosis brachyntera (Schwägr.) on the genus Pinus // Rozpravy ČSAV, Řada Matematických a Př́rodních Věd. Vol.10. P.1-104.

Spungis V. 2003. A checklist of Latvian Cecidomyiinae (Diptera, Cecidomyiidae) with notes on new records // Latvijas Entomologs. Vol.40. P.5-11.

Tigabu M., Oden P.C., Shen TongYun 2004. Application of nearinfrared spectroscopy for the detection of internal insect infestation in Picea abies seed lots // Canadian Journal of Forest Research. Vol.34. No.1. P.76-84.

Trepashko L.I., Boiko S.V., Slabozhankina O.F. 2012: Diptera in grain crops in Belarus // RPD Abstracts. Vol.1. P.7.

Tutin T.G., Heywood V.H., Burges N.A., Valentine D.H., Walters S.M., Webb A.A. 1964-1980. Flora Europaea. Cambridge: Univ. Press. Vol.1 (1964). 428 pp; Vol.2 (1968). 420 pp; Vol.3 (1972) 370 pp.; Vol.4 (1976). 505 pp.; Vol.5 (1980). 510 pp. 